\title{
Differences in cell death and cell cycle following fucoidan treatment in high-density HT-29 colon cancer cells
}

\author{
IN-HYE KIM $^{1}$, MI-JIN KWON ${ }^{1}$ and TAEK-JEONG NAM ${ }^{1,2}$ \\ ${ }^{1}$ Cell Biology Laboratory, Institute of Fisheries Sciences, Pukyong National University, Busan 46041; \\ ${ }^{2}$ Department of Food Science and Nutrition, Pukyong National University, Busan 48513, Republic of Korea
}

Received September 21, 2016; Accepted February 27, 2017

DOI: $10.3892 / \mathrm{mmr} .2017 .6520$

\begin{abstract}
Fucoidan, a sulfated polysaccharide present in marine brown seaweed, has been demonstrated to inhibit in vivo and in vitro growth of cells. The present study was conducted in HT-29 human colon cancer cells cultured at a high density, and examined the potential underlying mechanisms by which fucoidan exerts its anti-proliferative effects, which remain poorly understood. Fucoidan treatment of high-density HT-29 cells resulted in the inhibition of cell growth and increased apoptotic cell death. Flow cytometric analysis revealed that fucoidan treatment led to sub-G1 phase cell cycle arrest. This was associated with decreased protein expression levels of Retinoblastoma protein and E2 factor protein. In conclusion, the results of the present study demonstrated that fucoidan possesses anticancer activity against high density HT-29 cells by inhibiting cell growth and cell cycle progression.
\end{abstract}

\section{Introduction}

Colorectal cancer is the third most prevalent cancer worldwide. Treatment of this disease is challenging due to high rates of metastasis and recurrence $(1,2)$. Cell interactions in the tumor microenvironment may promote the survival, proliferation, malignancy and drug resistance of tumor cells (3). Accumulating evidence suggests a need to identify factors associated with this microenvironment, to develop strategies for the prevention of tumor progression (4-6).

Seaweeds have been extensively investigated as sources of natural bioactive compounds. Complex polysaccharides, including sulfated polysaccharides, from brown, red and green seaweeds exert a wide range of biological effects (7-9). Fucoidan, a fucose-rich polysaccharide present in brown seaweed, has been revealed to exert various biological effects,

Correspondence to: Professor Taek-Jeong Nam, Department of Food Science and Nutrition, Pukyong National University, 45 Yongso-ro, Nam-gu, Busan 48513, Republic of Korea

E-mail:namtj@pknu.ac.kr

Key words: fucoidan, high density, HT-29 colon cancer cell, cell growth, cell cycle progression including anticancer activities (10). Fucoidan induces tumor cell injury leading to growth arrest and tumor suppression via apoptosis (11). Previous studies have demonstrated that fucoidan is cytotoxic to a number of cancer cell types, and acts to increase apoptosis, and decrease invasion, metastasis and angiogenesis (12-15). In particular, apoptosis was induced in HT-29 colon cancer cells with treatment with a low concentration $(20 \mu \mathrm{g} / \mathrm{ml})$ fucoidan (16).

A number of studies have been performed using low molecular weight fucoidan $(17,18)$ and investigating the synergistic effects of fucoidan with other components (5), particularly chemotherapeutic agents. Fucoidan has been revealed to reduce the toxicity of certain anticancer drugs, and to prolong the survival of patients with unresectable advanced or recurrent colorectal cancer $(11,19)$.

Recent studies have indicated the influence of the microenvironment on tumor progression, including the inflammatory response $(3,20)$. Cell density is associated with environmental factors including accumulation of inhibitors, influence of substrates and exhaustion of essential nutrients or serum growth factor (21). Therefore, the aim of the present study was to investigate in detail the effects of fucoidan treatment on HT-29 colon cancer cells cultured at a high density.

\section{Materials and methods}

Fucoidan. Fucoidan purified from Fucus vesiculosus (catalog no. F5631) was purchased from Sigma-Aldrich; Merck KGaA (Darmstadt, Germany). Fucodian was dissolved in RPMI-1640 medium (Gibco; Thermo Fisher Scientific, Inc., Waltham, MA, USA) at concentrations of $100,250,500$ or $1,000 \mu \mathrm{g} / \mathrm{ml}$.

Cell culture. HT-29 human colon adenocarcinoma cells (catalog no. 30038) were purchased from the Korean Cell Line Bank (Seoul, Korea). The cells were cultured in RPMI-1640 medium supplemented with $10 \%$ fetal bovine serum (HyClone; GE Healthcare Life Sciences, Logan, UT, USA) containing $100 \mathrm{U} / \mathrm{ml}$ penicillin and $100 \mathrm{mg} / \mathrm{ml}$ streptomycin, in an incubator with $5 \% \mathrm{CO}_{2}$ at $37^{\circ} \mathrm{C}$. HT-29 cells were cultured at $50 \%$ growth $\left(4 \times 10^{4}\right.$ cells/well) at normal density and $80 \%$ growth at high density $\left(1 \times 10^{6}\right.$ cells/well).

Cell proliferation assay. Cell proliferation was estimated using a Cell Titer $96^{\circledR}$ Aqueous Non-Radioactive Cell Proliferation 
assay kit (catalog no. G5430; Promega Corporation, Madison, WI, USA). Cells were seeded in 96-well plates at a density of $1 \times 10^{6}$ cells/well in $100 \mu \mathrm{l}$ medium and allowed to attach for $24 \mathrm{~h}$. Attached cells were treated with 100, 250, 500 or $1,000 \mu \mathrm{g} / \mathrm{ml}$ fucoidan in serum-free medium (SFM) for 24 or $48 \mathrm{~h}$. The cell proliferation assay solution was added and incubated for $30 \mathrm{~min}$, and the absorbance of each well was measured at a wavelength of $490 \mathrm{~nm}$ using a Benchmark microplate reader (Bio-Rad Laboratories, Inc., Hercules, CA, USA).

Cell cytotoxicity assay. Cell cytotoxicity was estimated using a neutral red assay (22). Cells were seeded in 96-well plates at $1 \times 10^{6}$ cells/well in $100 \mu \mathrm{l}$ medium and allowed to attach for $48 \mathrm{~h}$. Attached cells were treated with 100, 250, 500 or $1,000 \mu \mathrm{g} / \mathrm{ml}$ fucoidan in SFM for 24 or $48 \mathrm{~h}$. Subsequently, $10 \mu \mathrm{g} / \mathrm{ml}$ Neutral Red solution and $50 \mathrm{mM}$ sodium citrate with $50 \%$ ethanol ( $\mathrm{pH} 4.2$ ) were added and incubated for $20 \mathrm{~min}$, and the absorbance of each well was measured at a wavelength of $510 \mathrm{~nm}$ using a Benchmark microplate reader (Bio-Rad Laboratories, Inc.).

Flow cytometric analysis. Cells were harvested and washed once with PBS, fixed with ice-cold $70 \%$ ethanol and stored at $4^{\circ} \mathrm{C}$. Prior to analysis, the cells were washed once again with PBS. The experiments were carried out using an Annexin V-fluorescein isothiocyanate (FITC) apoptosis detection kit (BD Biosciences, San Jose, CA, USA). Briefly, cells were resuspended at $1 \times 10^{6}$ cells/well in $100 \mu \mathrm{l}$ Annexin $\mathrm{V}$ binding buffer [10 mM 4-(2-hydroxyethyl)-1-piperazineethanesulfonic acid/NaOH (pH 7.4), $140 \mathrm{mM} \mathrm{NaCl}$ and $2.5 \mathrm{mM} \mathrm{CaCl}]$. Annexin V-FITC and propidium iodide (PI) were subsequently added, according to the manufacturer's protocol, and cells were incubated on ice for $15 \mathrm{~min}$ in the dark. Cells were acquired using a FACSCalibur flow cytometer (BD Biosciences).

Cell cycle analysis. Cells were harvested and washed once with PBS, fixed with ice-cold $70 \%$ ethanol and stored at $4^{\circ} \mathrm{C}$. Prior to analysis, the cells were washed once again with $\mathrm{PBS}$, resuspended in $1 \mathrm{ml}$ PI solution $[0.1 \mathrm{mg} / \mathrm{ml}$ RNase A, $50 \mu \mathrm{g} / \mathrm{ml}$ PI, $0.1 \%(\mathrm{w} / \mathrm{v})$ sodium citrate and $0.1 \%$ (v/v) NP-40], and incubated on ice for $30 \mathrm{~min}$ in the dark. Cells were acquired using a flow cytometer (FACSCalibur), and CellQuest ${ }^{\mathrm{TM}}$ analysis program software, version 5.1 (BD Biosciences) was used to determine the relative DNA content based on the presence of red fluorescence.

Hoechst 33342 staining. HT-29 cells were cultured for $48 \mathrm{~h}$ in SFM containing fucoidan. Subsequently, cells were washed with PBS and fixed with $10 \%$ formaldehyde. Cells were washed once again with PBS, following which $2 \mu \mathrm{g} / \mathrm{ml}$ Hoechst 33342 solution was added. Cells were incubated for $30 \mathrm{~min}$ at room temperature in the dark, and observed under a fluorescence microscope.

Western blot analysis. HT-29 cells were cultured with 0, 250, 500 or $1,000 \mu \mathrm{g} / \mathrm{ml}$ fucoidan for $48 \mathrm{~h}$. Subsequently, cells were washed with PBS and lysed in radioimmunoprecipitation assay lysis buffer (20 mM Tris, $1 \mathrm{mM}$ EDTA, $150 \mathrm{mM}$ sodium chloride, $1 \mathrm{mM}$ EGTA, 1\% Triton X-100, $2.5 \mathrm{mM}$ sodium pyrophosphate; $\mathrm{pH}$ 7.5) containing protease inhibitors (1 $\mu \mathrm{g} / \mathrm{ml}$ leupeptin, $1 \mathrm{mM} \beta$-glycerophosphate, $1 \mathrm{mM}$ phenylmethanesulfonyl fluoride and $1 \mathrm{mM}$ sodium orthovanadate) on ice for $30 \mathrm{~min}$. The extracts were centrifuged at 9,750 x $\mathrm{g}$ for $10 \mathrm{~min}$ at $4^{\circ} \mathrm{C}$ and the supernatant was used for western blot analysis.

Total protein $(40 \mu \mathrm{g})$ was electrophoresed on $10-15 \%$ SDS-PAGE gels and transferred to polyvinylidene difluoride membranes (EMD Millipore, Billerica, MA, USA). Membranes were blocked with $1 \%$ bovine serum albumin (BSA; GenDepot Inc., Barker, TX, USA) in TBS (5 mM Tris- $\mathrm{HCl}, 20 \mathrm{mM}$ sodium chloride; $\mathrm{pH}$ 7.4) containing $0.1 \%$ Tween-20 (TBST) and incubated with primary antibodies diluted 1:1,000 in 1\% BSA-TBST with gentle shaking at $4^{\circ} \mathrm{C}$ overnight. Membranes were washed twice with TBST for 15 min each time, following which the membranes were incubated with corresponding horseradish peroxidase-conjugated (HRP) secondary antibodies (diluted 1:10,000) for $2 \mathrm{~h}$ at room temperature. Following a final wash, protein bands were detected using a SuperSignal West Dura Extended Duration Substrate kit (Thermo Fisher Scientific, Inc.) and developed using Kodak X-ray film (Eastman Kodak Company, Rochester, NY, USA). Densitometry results were visualized on the Fujifilm Multi Gauge system version 3.0 program (Fujifilm, Tokyo, Japan). The following primary antibodies were used: anti-FAS (catalog no. se-7886; anti-rabbit), anti-pro-caspase-8 (catalog no. sc-7890; anti-rabbit), anti-pro-caspase-9 (catalog no. sc-7885; anti-rabbit), anti-pro-caspase-7 (catalog no. sc-6138; anti-goat), anti-pro-caspase-3 (catalog no. sc-7148; anti-rabbit), anti-Bcl-2 (catalog no. sc-492; anti-rabbit), anti-Bcl-xL (catalog no. sc-7195; anti-rabbit), anti-Bad (catalog no. sc-7869; anti-rabbit), anti-Bax (catalog no. sc-493; anti-rabbit), anti-cyclin D1 (catalog no. sc-753; anti-rabbit), anti-phospho-RB (catalog no. sc-21875; anti-goat), anti-E2F (catalog no. sc-251; anti-mouse) and anti- $\beta$-actin (catalog no. sc-47,778; anti-mouse). These were all obtained from Santa Cruz Biotechnology, Inc. (Dallas, TX USA). The secondary antibodies used were HRP-conjugated anti-mouse IgG (catalog no. sc-2031; Santa Cruz Biotechnology, Inc.), anti-rabbit (catalog no. A-0545; Sigma-Aldrich), and anti-goat (catalog no. A50-101P; Bethyl Laboratories Inc., Montgomery, TX, USA).

Statistical analysis. Data are presented as the mean \pm standard deviation of at least three independent experiments. Significant differences among multiple mean values were assessed by one-way analysis of variance followed by the Duncan's multiple range test using PASW software version 18 (SPSS, Inc., Chicago, IL, USA). $\mathrm{P}<0.05$ was considered to indicate a statistically significant difference.

\section{Results}

Effect of fucoidan on growth of HT-29 colon cancer cells. Previous studies have demonstrated that low concentrations $(0-20 \mu \mathrm{g} / \mathrm{ml})$ of fucoidan induce apoptosis (16). The present study aimed to assess the effect of high concentration $(0-1,000 \mu \mathrm{g} / \mathrm{ml})$ fucoidan in high density cells $\left(1 \times 10^{6}\right.$ cells/well $)$. Prior to assessing the effect of fucoidan on the viability in HT-29 cells cultured at a high density, the toxicity of fucoidan 
was evaluated using high concentrations. As determined by the neutral red assay, cytotoxicity was not detected at any concentration of fucoidan assessed (Fig. 1A). To investigate the effect of fucoidan on cell growth, HT-29 cells were treated with $0-1,000 \mu \mathrm{g} / \mathrm{ml}$ fucoidan for 24 or $48 \mathrm{~h}$. As presented in Fig. 1B, cell growth was significantly inhibited following treatment with $500 \mu \mathrm{g} / \mathrm{ml}$ fucoidan for $48 \mathrm{~h}$ compared with control untreated cells.

Effect of fucoidan on apoptosis of HT-29 colon cancer cells. Subsequently, it was analyzed whether the growth inhibitory effect of fucoidan was due to apoptosis. Apoptosis was evaluated using two separate assays. Cells double positive for Annexin V-FITC and PI (late apoptotic or necrotic cells) were observed $48 \mathrm{~h}$ following fucoidan treatment (Fig. 2A) and increased in a dose-dependent manner (Fig. 2B). In addition, the effect of fucoidan treatment on the nuclear morphology of HT-29 cells was analyzed to determine whether apoptosis was involved in fucoidan-induced cell death. Condensed and fragmented nuclei and a reduced cell volume were evident in $1,000 \mu \mathrm{g} / \mathrm{ml}$ fucoidan-treated cells, in contrast to untreated cells. These observations indicated that the decrease in cell viability observed following fucoidan treatment is associated with the induction of cell death.

Effect of fucoidan on cell death-associated protein expression levels in HT-29 colon cancer cells. The effect of fucoidan treatment on the cell death characteristics of high-density HT-29 cells was assessed. Western blot analysis revealed that fucoidan had effects on various cell death-associated proteins, including decreased pro-caspase-9, pro-caspase-7, pro-caspase-3, Bcl-2, Bcl-xL and increased Fas and Bax protein expression levels (Fig. 3).

The cell cycle phage distribution of exponentially growing HT-29 cells was analyzed following fucoidan treatment. Compared with the untreated control, fucoidan-treated cells accumulated in the sub-G1 phase of the cell cycle (Fig. 4A). To further investigate the molecular mechanisms underlying fucoidan-induced sub-G1 arrest, the HT-29 cells were treated with fucoidan, and western blot analysis was performed to detect cell cycle progression-associated proteins. Fucoidan treatment decreased the protein expression levels of phosphorylated $\mathrm{Rb}$ protein and E2F (Fig. 4B). However, fucoidan did not significantly affect the protein expression levels of cyclin D1. Therefore, fucoidan treatment may inhibit cell cycle progression in high-density HT-29 cells, and this may be associated with the suppression of cancer cell proliferation induced by fucoidan.

\section{Discussion}

Cell density is an important factor that affects the metastatic aggressiveness of cancer cells (4). The generation of cancer cells is due to accumulated abnormalities in multiple cell regulatory systems and is reflected in various aspects of cell behavior $(4,23)$. The metastatic activity of cancer cells may be suppressed by alterations in the environment, including cell density $(4,21)$. Cell density may be regulated by the Yes-associated protein-mediated Hedgehog signaling pathway (24).
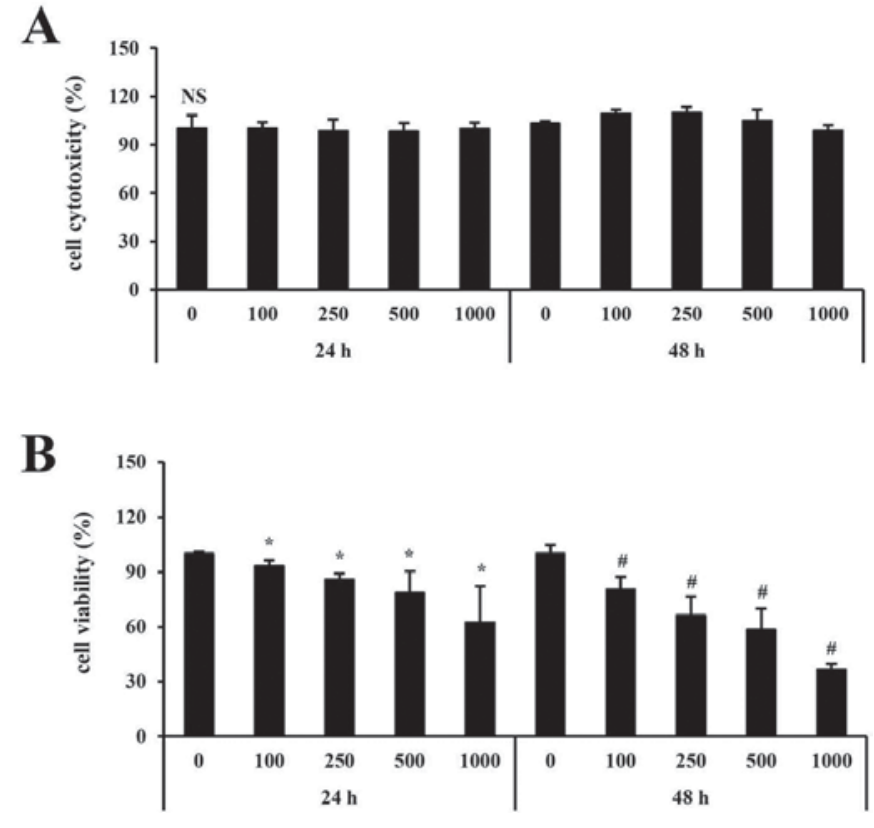

Figure 1. Effect of fucoidan on the growth of HT-29 colon cancer cells. HT-29 cells were seeded in 96-well plates at a density of $1 \times 10^{6}$ cells/well and subsequently treated with $0-1,000 \mu \mathrm{g} / \mathrm{ml}$ fucoidin for $24 \mathrm{~h}$ or $48 \mathrm{~h}$. (A) Cytotoxic cells were estimated by the neutral red assay, and (B) viable cells were estimated by the proliferation assay. Data are expressed as the mean \pm standard deviation. According to Duncan's multiple range test, ${ }^{*} \mathrm{P}<0.05$ vs. control group; ${ }^{\#} \mathrm{P}<0.05$ vs. control group. NS, not significant.

There is increased interest in the use of bioactive natural compounds for the treatment of various diseases, including cancer. Of various marine resources, algae are particularly important sources of these compounds.

Fucoidan is a primary sulfated polysaccharide present in brown seaweed. It has been well characterized and revealed to have various biological functions $(9,10,15)$. It has recently been reported that fucoidan may have therapeutic potential for the treatment of inflammatory diseases (25) and microglia activation-mediated neurodegenerative diseases $(26,27)$. Furthermore, fucoidan inhibits cancer cell proliferation and suppresses cell growth by inducing apoptosis and cell cycle arrest (12-14). However, this effect is limited in terms of cancer cell and the molecular mechanisms underlying its antiproliferative effects in different cellular environments, including high or low cell densities, remain to be fully elucidated.

Fucoidan has been widely investigated due to its anticancer effects and low toxicity. Previous studies have demonstrated fucoidan to be a potential preventive or therapeutic agent in cancer $(13,20)$. The antitumor effects of fucoidan may be associated with the inhibition of tumorigenesis via the induction of cell death.

Previous studies suggest that tumor progression is influenced by the microenvironment, including the inflammatory response $(3,20)$. Cell density has been demonstrated to be associated with environmental factors including accumulation of inhibitors, substrates and exhaustion of essential nutrient or serum growth factor (21). However, the specific mechanisms underlying the anticancer effects of fucoidan with regards to the cellular environment remain to be fully elucidated. The present study aimed to assess the association between cell density and environmental factors in HT-29 colon cancer cells. 
A

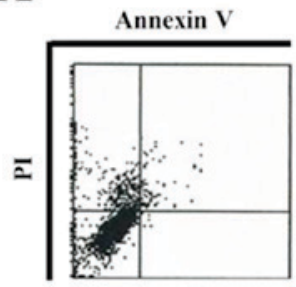

0

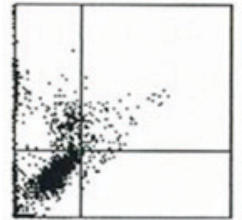

125

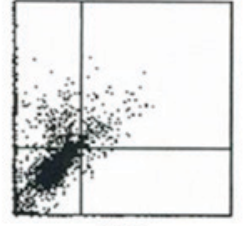

250

Fucoidan $(\mu \mathrm{g} / \mathrm{m} 1)$

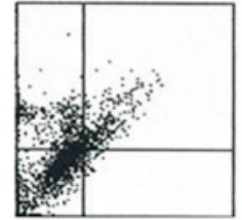

500

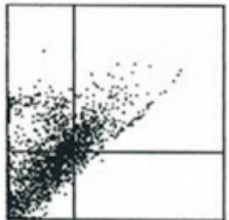

1000

B

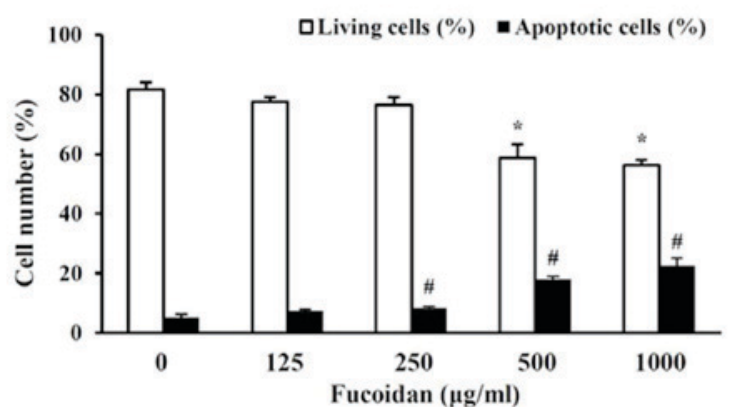

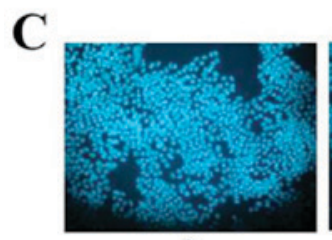

0

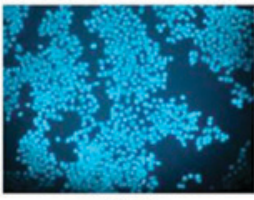

125

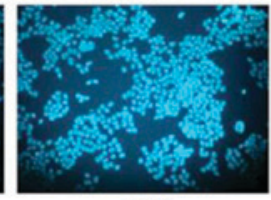

250

Fucoidan $(\mu \mathrm{g} / \mathrm{ml})$

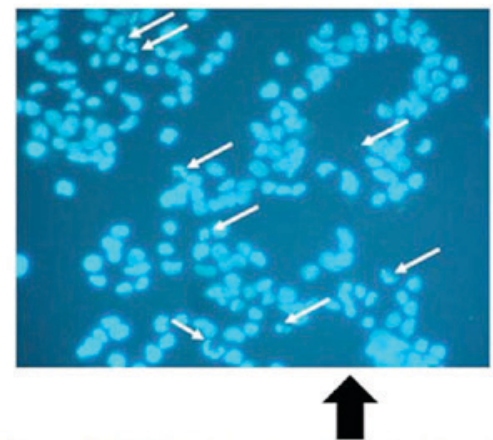

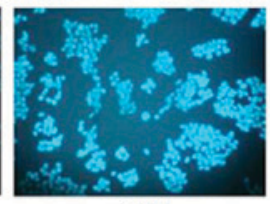

500

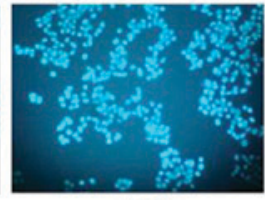

1000

Figure 2. Effect of fucoidan on the apoptosis of HT-29 colon cancer cells. HT-29 cells were treated with 0-1,000 $\mu \mathrm{g} / \mathrm{ml}$ fucoidan for $48 \mathrm{~h}$. (A) Cells were stained with PI and Annexin V, and analyzed by flow cytometry. The living cells are indicated in the lower left region, and 'apoptotic cells' indicates the cells in early stages of apoptosis in the upper right region. Cells in late apoptotic stages were indicated in the lower right region. (B) The percentages of living and apoptotic cells of total cells were quantified from the flow cytometric analysis. (C) Cells were fixed and stained with Hoechst 33342 . Nuclear morphology was imaged using a fluorescence microscope (magnification x200). Arrows indicate typical apoptotic cells containing apoptotic bodies (magnification, $\mathrm{x} 400$ ). Data was expressed as the mean \pm standard deviation. According to Duncan's multiple range test, ${ }^{*} \mathrm{P}<0.05$ vs. control group; ${ }^{\prime} \mathrm{P}<0.05$ vs. control group.

Following this, the effects of fucoidan treatment on HT-29 colon cancer cells cultured at a high density were investigated.

Previous studies used cells at a normal density of $4 \times 10^{4}$ cells/well and low concentrations of $0-20 \mu \mathrm{g} / \mathrm{ml}$ were used. However, in the present study, a high density of $1 \times 10^{6}$ cells/well and a low concentration of $0-1,000 \mu \mathrm{g} / \mathrm{ml}$ were used to investigate cell viability and cytotoxicity.

Cytotoxicity was not detected at any concentration $(0-1,000 \mu \mathrm{g} / \mathrm{ml})$ or time point $(24,48 \mathrm{~h})$ with fucoidan treatment. Cell viability was significantly inhibited following treatment of fucoidan compared with untreated cells. In particular, the viability was reduced to $50 \%$ at $500 \mu \mathrm{g} / \mathrm{ml}$ concentration when treated with fucoidan for $48 \mathrm{~h}$.

Following this, inhibition of cell viability with treatment of fucoidan was analyzed by flow cytometry using an Annexin V-FITC apoptosis detection kit. The number of living cells in the untreated group was $81.6 \pm 2.4 \%$, however decreased to $58.7 \pm 4.4 \%$ with $500 \mu \mathrm{g} / \mathrm{ml}$ fucoidan. In addition, apoptotic cells, when treated with fucoidan, were increased to $7.43 \pm 0.5 \%$ at $100 \mu \mathrm{g} / \mathrm{ml}$ and $22.5 \pm 2.5 \%$ at $1,000 \mu \mathrm{g} / \mathrm{ml}$ compared with untreated cells $(5.17 \pm 1.1 \%)$.

Typically, morphological alterations, including destruction of the cell membrane and condensation of the chromosome and formation of apoptotic bodies, occur in the process of cell apoptosis. The morphological alterations of nuclei were investigated in order to provide direct evidence of apoptosis with treatment of fucoidan. Apoptotic bodies were detected by DNA fragmentation specific to nuclei. Therefore, inhibition of viability of HT-29 cells with fucoidan treatment was closely associated with the induction of apoptosis and DNA synthesis.

The effect of fucoidan treatment on apoptotic characteristics of high-density HT-29 cells was examined. Western blot analysis revealed that fucoidan had effects on various apoptosis-associated and survival proteins.

Receptors including Fas are important in the physiological regulation of apoptosis. Apoptosis is triggered by these factors and acts as a defense against diseases that occur in various tumors or disorders of the immune system. In addition, apoptosis is an important mechanism that maintains homeostasis $(28,29)$. The Fas receptor is activated when the Fas binds to Fas ligand. The death-inducing signaling complex (DISC) is formed by the binding of the Fas-associated death domain (FADD) to the death domain of the cytoplasmic tail. Then, pro-caspase- 8 binds to the death effector domain of FADD. Pro-caspase- 8 bound to FADD is activated by autocleavage $(30,31)$.

In present study, the extrinsic pathway was investigated via the protein expression levels of Fas and pro-caspase- 8 

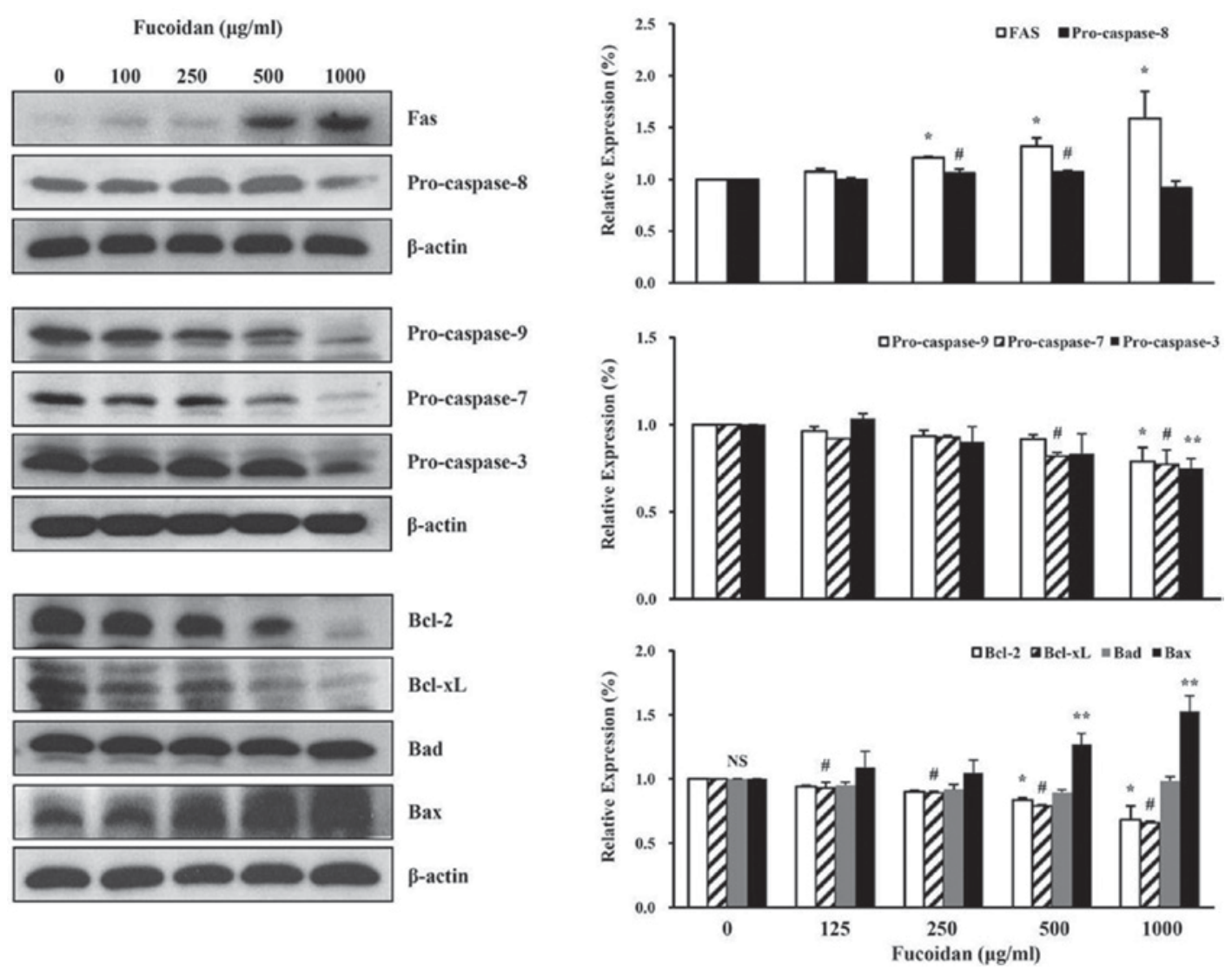

Figure 3. Effect of fucoidan on cell death-associated protein expression levels in HT-29 colon cancer cells. Following fucoidan treatment, western blotting was performed to detect the cell death-associated proteins Fas, pro-caspase-8, pro-caspase-9, pro-caspase-7, pro-caspase-3, Bcl-2, Bcl-xL, Bad and Bax; $\beta$-actin served as a loading control. Data was expressed as the mean \pm standard deviation. According to Duncan's multiple range test, " $\mathrm{P}<0.05$ vs. control group (Fas, pro-caspase-9, Bcl-2); " $\mathrm{P}<0.05$ vs. control group (pro-caspase-8, pro-caspase-7, Bcl-xL); ${ }^{* *} \mathrm{P}<0.05$ vs. control group (pro-caspase-3, Bax). NS, not significant. Bcl-2, B-cell lymphoma 2; Bcl-xL, B-cell lymphoma-extralarge; Bad, B-cell lymphoma 2-associated death promoter; Bax, B-cell lymphoma 2-associated $\mathrm{X}$ protein.

A
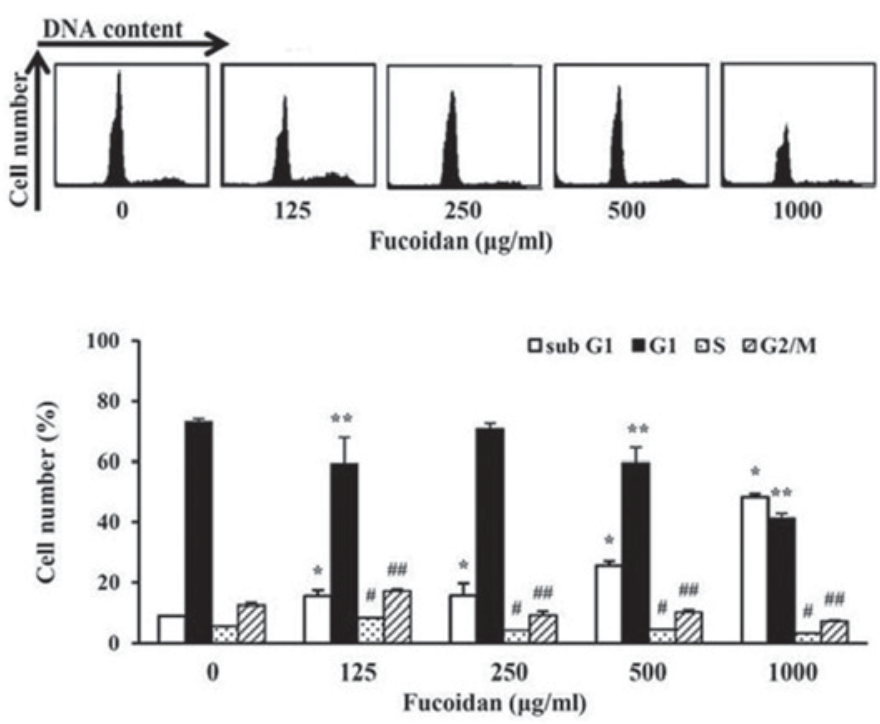

B
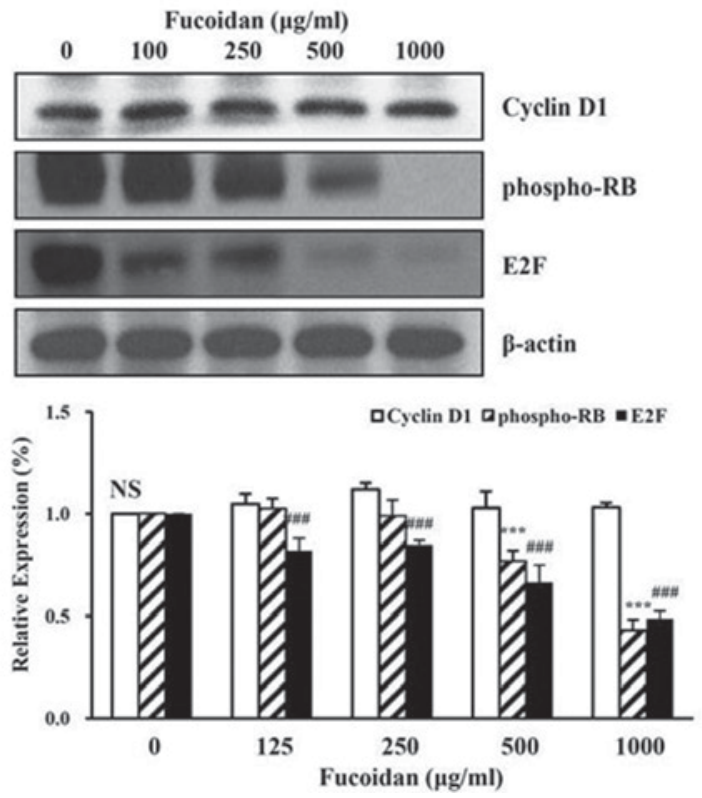

Figure 4. Effect of fucoidan on cell cycle progression in HT-29 colon cancer cells. HT-29 cells were treated with 0-1,000 $\mu \mathrm{g} / \mathrm{ml}$ fucoidan for $48 \mathrm{~h}$. (A) Flow cytometric analysis of cell cycle progression in HT-29 cells following fucoidan treatment. The cells with hypodiploid DNA (sub-G1 phase) contents are undergoing apoptotic DNA degradation. (B) Western blot analysis of the cell cycle-associated proteins cyclin D1, phospho-RB and E2F; $\beta$-actin served as a loading control. Data was expressed as the mean \pm standard deviation. According to Duncan's multiple range test, ${ }^{*} \mathrm{P}<0.05$ vs. control group; ${ }^{* *} \mathrm{P}<0.05$ vs. control group; ${ }^{\#} \mathrm{P}<0.05$ vs. control group; ${ }^{\# \#} \mathrm{P}<0.05$ vs. control group; ${ }^{* * *} \mathrm{P}<0.05$ vs. control group; ${ }^{\# \# "} \mathrm{P}<0.05$ vs. control group. NS, not significant. Phospho-RB, phosphorylated Retinoblastoma protein; E2F, E2 factor. 
in high density HT-29 cells treated with fucoidan. Fucoidan treatment increased the expression levels of the Fas protein in a dose-dependent manner and decreased the expression levels of pro-caspase- 8 protein (Fig. 3). The intrinsic pathway was additionally investigated, with the protein expression levels of pro-caspase- $9,-7$ and -3 in high density of HT-29 cells treated with fucoidan. Treatment with this reagent decreased the protein expression levels of pro-caspase-9, -7 and -3 (Fig. 3).

The present study investigated if fucoidan affects the Bcl-2 family signaling associated with cell survival (Bcl-2 and Bcl-xL) and cell death (Bad and Bax). Fucoidan treatment increased the expression level of Bax protein in a concentration-dependent manner, and decreased the expression levels of Bcl-2, and Bcl-xL (Fig. 3).

The present study demonstrated that a high-concentration of fucoidan induced a decrease in cell viability and morphological changes including nuclear fragmentation. Therefore, characterization of apoptosis was investigated in the cell cycle of HT-29 high-density cells treated with fucoidan. The number of cells in the sub-G1 phase, when treated with fucoidan, was increased to $15.3 \pm 2.0 \%$ at $100 \mu \mathrm{g} / \mathrm{ml}$ and $48.3 \pm 1.0 \%$ at $1,000 \mu \mathrm{g} / \mathrm{ml}$ compared with untreated cells $(9.0 \pm 0.1 \%$ ) (Fig. 4A). Conversely, the number of cells in G1, $\mathrm{S}, \mathrm{G} 2 / \mathrm{M}$ phase were decreased compared with untreated cells.

The present study then investigated the expression levels of proteins that regulate the cell cycle of the G1 phase. The level of cyclin D1 protein expression was not affected by treatment with fucoidan (Fig. 4B). The phosphorylation level of $\mathrm{RB}$ proteins that regulate the $\mathrm{S}$ phase transition in $\mathrm{G} 1$ were examined. The phosphorylation level of RB was decreased in a dose-dependent manner with fucoidan treatment. The E2F protein was inhibited by binding to phosphor-RB in the G1 phase. The expression level of E2F protein decreased in a dose-dependent manner with fucoidan treatment (Fig 4B). These results suggested that the decreased DNA synthesis inhibited phosphorylation of the RB protein by creating a complex between E2F and the RB protein. Therefore, treatment with a high concentration of fucoidan arrested the G1 phase and inhibited cell growth (cell viability).

The present study was conducted on high-density cultured HT-29 colon cancer cells to investigate the potential mechanisms by which fucoidan exerts its effects. The association between cellular environment and the functional effects of fucoidan should be considered during future studies and the development of fucoidan as a potential therapeutic agent for the treatment of cancer.

\section{Acknowledgements}

The present study was supported by Pukyong National University (grant no. C-D-2015-0953) Busan, Republic of Korea.

\section{References}

1. Jemal A, Murray T, Ward E, Samuels A, Tiwari RC, Ghafoor A, Feuer EJ and Thun MJ: Cancer statistics, 2005. CA Cancer J Clin 55: 10-30, 2005.

2. Jemal A, Center MM, Ward E and Thun MJ: Cancer occurrence. Methods Mol Biol 471: 3-29, 2009.
3. Pin AL, Houle F and Huot J: Recent advances in colorectal cancer research: The microenvironment impact. Cancer Microenviron 4: 127-131, 2011.

4. Kuwano H, Miyazaki T, Tsutsumi S, Hirayama I, Shimura T, Mochiki E, Nomoto K, Fukuchi M, Kato H and Asao T: Cell density modulates the metastatic aggressiveness of a mouse colon cancer cell line, colon 26. Oncology 67: 441-449, 2004.

5. Ikeguchi M, Yamamoto M, Arai Y, Maeta Y, Ashida K, Katano K, Miki Y and Kimura T: Fucoidan reduces the toxicities of chemotherapy for patients with unresectable advanced or recurrent colorectal cancer. Oncol Lett 2: 319-322, 2011.

6. Buhrmann C, Kraehe P, Lueders C, Shayan P, Goel A and Shakibaei M: Curcumin suppresses crosstalk between colon cancer stem cells and stromal fibroblasts in the tumor microenvironment: potential role of EMT. PLoS One 9: e107514, 2014.

7. Cian RE, Drago SR, de Medina FS and Martínez-Augustin O: Proteins and carbohydrates from red seaweeds: evidence for beneficial effects on gut function and microbiota. Mar Drugs 13: 5358-5383, 2015

8. Park HK, Kim IH, Kim J and Nam TJ: Induction of apoptosis and the regulation of ErbB signaling by laminarin in HT-29 human colon cancer cells. Int J Mol Med 32: 291-295, 2013.

9. Min EY, Kim IH, Lee J, Kim EY, Choi YH and Nam TJ: The effects of fucoidan on senescence are controlled by the p16 $6^{\text {INK4a }}$-pRb and P-14 $14_{-}^{\text {Arf }}$-p53 pathways in hepatocellular carcinoma and hepatic cell lines. Int J Oncol 45: 47-56, 2014.

10. Atashrazm F, Lowenthal RM, Woods GM, Holloway AF and Dickinson JL: Fucoidan and cancer: a multifunctional molecule with anti-tumor potential. Mar Drugs 13: 2327-2346, 2015.

11. Masahide I, Hiroaki S, Yasunari M and Takayuki K: Effect of fucoidan dietary supplement on the chemotherapy treatment of patients with unresectable advanced gastric cancer. J Cancer Ther 6: 1020-1026, 2015.

12. Hyun JH, Kim SC, Kang JI, Kim MK, Boo HJ, Kwon JM, Koh YS, Hyun JW, Park DB, Yoo ES and Kang HK: Apoptosis inducing activity of fucoidan in HCT-15 colon carcinoma cells. Biol Pharm Bull 32: 1760-1764, 2009.

13. Boo HJ, Hong JY, Kim SC, Kang JI, Kim MK, Kim EJ, Hyun JW, Koh YS, Yoo ES, Kwon JM and Kang HK: The anticancer effect of fucoidan in PC-3 prostate cancer cells. Mar Drugs 11: 2982-2999, 2013

14. Park HY, Choi IW, Kim GY, Kim BW, Kim WJ and Choi YH: Fucoidan induces G1 arrest of the cell cycle in EJ human bladder cancer cells through down-regulation of $\mathrm{pRB}$ phosphorylation. Revista Brasileira de Farmacognosia 25: 246-251, 2015.

15. Dithmer M, Fuchs S, Shi Y, Schmidt H, Richert E, Roider J and Klettner A: Fucoidan reduces secretion and expression of vascular endothelial growth factor in the retinal pigment epithelium and reduces angiogenesis in vitro. PLoS One 9: 1-10, 2014.

16. Kim EJ, Park SY, Lee JY and Park JH: Fucoidan present in brown algae induces apoptosis of human colon cancer cells. BMC Gastroenterol 10: 96, 2010.

17. Xu Y, Zhang Q, Luo D, Wang J and Duan D: Low molecular weight fucoidan modulates P-selectin and alleviates diabetic nephropathy. Int J Biol Macromol 91: 233-240, 2016.

18. Zhao X, Guo F, Hu J, Zhang L, Xue C, Zhang Z and Li B: Antithrombotic activity of oral administered low molecular weight fucoidan from Laminaria Japonica. Thromb Res 144: 46-52, 2016.

19. Atashrazm F, Lowenthal RM, Dickinson JL, Holloway AF and Woods GM: Fucoidan enhances the therapeutic potential of arsenic trioxide and all-trans retinoic acid in acute promyelocytic leukemia, in vitro and in vivo. Oncotarget 7: 46028-46041, 2016.

20. Gout S and Huot J: Role of cancer microenvironment in metastasis: focus on colon cancer. Cancer Microenviron 1: 69-83, 2008.

21. Birch JR and Cartwright T: Environmental factors influencing the growth of animal cells in culture. J Chem Tech Biotechnol 32: 313-317, 1982.

22. Wadsworth TL and Koop DR: Effects of the wine polyphenolics quercetin and resveratrol on pro-inflammatory cytokine expression in RAW 264.7 macrophages. Biochem Pharmacol 57: 941-949, 1999.

23. Córdoba-Pedregosa Mdel C, Villalba JM, González-Aragón D, Bello RI and Alcaín FJ: Cellular density and cell type are the key factors in growth inhibition induced by 2,5Bis [1-aziridinyl]-1,4 benzoquinone (DZQ). Anticancer Res 26: 3535-3540, 2006.

24. Tariki M, Dhanyamraju PK, Fendrich V, Borggrefe T, Feldmann G and Lauth M: The Yes-associated protein controls the cell density regulation of Hedgehog signaling. Oncogenesis 3: e112, 2014. 
25. Cui YQ, Jia YJ, Zhang T, Zhang QB and Wang XM: Fucoidan protects against lipopolysaccharide-induced rat neuronal damage and inhibits the production of proinflammatory mediators in primary microglia. CNS Neurosci Ther 18: 827-833, 2012.

26. Park HY, Han MH, Park C, Jin CY, Kim GY, Choi IW, Kim ND, Nam TJ, Kwon TK and Choi YH: Anti-inflammatory effects of fucoidan through inhibition of NF-kB, MAPK and Akt activation in lipopolysaccharide-induced BV2 microglia cells. Food Chem Toxicol 49: 1745-1752, 2011.

27. Zhang FL, He Y, Zheng Y, Zhang WJ, Wang Q, Jia YJ, Song HL, An HT, Zhang HB, Qian YJ, et al: Therapeutic effects of fucoidan in 6-hydroxydopamin-lesioned rat model of Parkinson's disease: role of NADPH oxidase-1. CNS Neurosci Ther 20: 1036-1044, 2014
28. Siegel RM, Chan FK, Chun HJ and Lenardo MJ: The multifaceted role of Fas signaling in immune cell homeostasis and autoimmunity. Nat Immunol 1: 469-474, 2000.

29. Wajant H: The Fas signaling pathway: more than a paradigm. Science 296: 1635-1636, 2002.

30. Budihardjo I, Oliver H,Letter M,Luo X and Wang X: Biochemical pathways of caspase activation during apoptosis. Annu Rev Cell Dev Biol 15: 269-290, 1999.

31. Thornberry $\mathrm{N}$ and Lazebnik Y: Caspase: enemies within. Science 281: 1312-1316, 1998. 